\title{
Front Matter: Volume 9828
}

, "Front Matter: Volume 9828," Proc. SPIE 9828, Airborne Intelligence, Surveillance, Reconnaissance (ISR) Systems and Applications XIII, 982801 (22 June 2016); doi: 10.1117/12.2245356

SPIE. Event: SPIE Defense + Security, 2016, Baltimore, MD, United States 


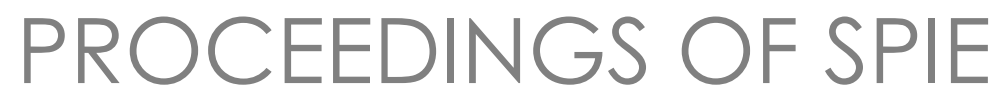

\section{Airborne Intelligence, Surveillance, Reconnaissance (ISR) Systems and Applications XIII}

Daniel J. Henry

Gregory J. Gosian

Davis A. Lange

Dale Linne von Berg

Thomas J. Walls

Darrell L. Young

Editors

18-19 April 2016

Baltimore, Maryland, United States

Sponsored and Published by

SPIE 
The papers in this volume were part of the technical conference cited on the cover and title page. Papers were selected and subject to review by the editors and conference program committee. Some conference presentations may not be available for publication. Additional papers and presentation recordings may be available online in the SPIE Digital Library at SPIEDigitallibrary.org.

The papers reflect the work and thoughts of the authors and are published herein as submitted. The publisher is not responsible for the validity of the information or for any outcomes resulting from reliance thereon.

Please use the following format to cite material from this book:

Author(s), "Title of Paper," in Airborne Intelligence, Surveillance, Reconnaissance (ISR) Systems and Applications XIII, edited by Daniel J. Henry, Gregory J. Gosian, Davis A. Lange, Dale Linne von Berg, Thomas J. Walls, Darrell L. Young, Proceedings of SPIE Vol. 9828 (SPIE, Bellingham, WA, 2016) Six-digit Article CID Number.

ISSN: 0277-786X

ISSN: 1996-756X (electronic)

ISBN: 9781510600690

Published by

SPIE

P.O. Box 10, Bellingham, Washington 98227-0010 USA

Telephone +1 3606763290 (Pacific Time) · Fax +1 3606471445

SPIE.org

Copyright (C) 2016, Society of Photo-Optical Instrumentation Engineers.

Copying of material in this book for internal or personal use, or for the internal or personal use of specific clients, beyond the fair use provisions granted by the U.S. Copyright Law is authorized by SPIE subject to payment of copying fees. The Transactional Reporting Service base fee for this volume is $\$ 18.00$ per article (or portion thereof), which should be paid directly to the Copyright Clearance Center (CCC), 222 Rosewood Drive, Danvers, MA 01923. Payment may also be made electronically through CCC Online at copyright.com. Other copying for republication, resale, advertising or promotion, or any form of systematic or multiple reproduction of any material in this book is prohibited except with permission in writing from the publisher. The CCC fee code is 0277-786X/16/\$18.00.

Printed in the United States of America.

Publication of record for individual papers is online in the SPIE Digital Library.

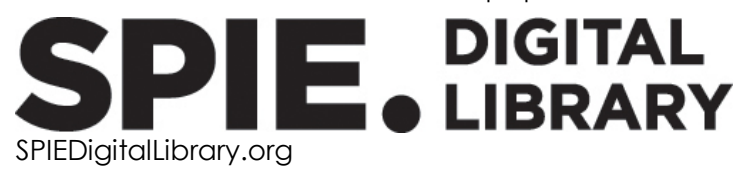

Paper Numbering: Proceedings of SPIE follow an e-First publication model, with papers published first online and then in print. Papers are published as they are submitted and meet publication criteria. A unique citation identifier (CID) number is assigned to each article at the time of the first publication. Utilization of CIDs allows articles to be fully citable as soon as they are published online, and connects the same identifier to all online, print, and electronic versions of the publication. SPIE uses a six-digit CID article numbering system in which:

- The first four digits correspond to the SPIE volume number.

- The last two digits indicate publication order within the volume using a Base 36 numbering system employing both numerals and letters. These two-number sets start with 00, 01, 02, 03, 04, $05,06,07,08,09,0 A, 0 B \ldots$ OZ, followed by 10-1Z, 20-2Z, etc.

The CID Number appears on each page of the manuscript. The complete citation is used on the first page, and an abbreviated version on subsequent pages. 


\title{
Contents
}

\author{
$\checkmark \quad$ Authors \\ vii Conference Committee \\ ix Introduction
}

\section{SESSION 1 ISR: PLATFORMS AND MISSIONS}

982802 ISR systems: Past, present, and future (Invited Paper) [9828-1]

982803 A framework for autonomous and continuous aerial intelligence, surveillance, and reconnaissance operations [9828-2]

982806 An aerial 3D printing test mission [9828-5]

\section{SESSION 2 ISR: OPTICS AND STABILIZATION}

982808 Laser-based satellite communication systems stabilized by non-mechanical electro-optic scanners [9828-7]

982809 Piezo-based miniature high resolution stabilized gimbal [9828-8]

\section{SESSION $3 \quad$ ISR: SENSORS AND SYSTEMS}

9828 OB The eyes of LITENING [9828-1 1]

\section{SESSION 4 ISR: INFORMATION EXTRACTION/QUANTIFICATION}

9828 OC Precision optical navigation guidance system [9828-12]

9828 OD Pattern of life analysis for diverse data types [9828-13]

$9828 \mathrm{OE}$ Automated video quality measurement based on manmade object characterization and motion detection [9828-14]

9828 OF A study of the effects of degraded imagery on tactical 3D model generation using structure-from-motion [9828-15] 
9828 0G Development of a real-time neural network estimator to improve defense capabilities of HEO satellites [9828-16]

9828 Ol Automatic construction of aerial corridor for navigation of unmanned aircraft systems in class $\mathbf{G}$ airspace using LiDAR [9828-18]

$9828 \mathrm{0J}$ High-performance image deinterlacing using optical flow and artifact post-processing on GPU/CPU for surveillance and reconnaissance tasks [9828-19]

9828 OK Improving detection of low SNR targets using moment-based detection [9828-20] 


\section{Authors}

Numbers in the index correspond to the last two digits of the six-digit citation identifier (CID) article numbering system used in Proceedings of SPIE. The first four digits reflect the volume number. Base 36 numbering is employed for the last two digits and indicates the order of articles within the volume. Numbers start with 00, 01, 02, 03, 04, 05, 06, 07, 08, 09, 0A, 0B...0Z, followed by 10-1Z, 20-2Z, etc.

Algire, C., OE

Anderson, Mike, 08

Bolick, Leslie, OF

Cheng, Hui, OD

Davis, Scott R., 08

Dellosa, M., OC

Fallahpour, A., OC

Feng, Dengchao, 0 I

Ferraro, Joseph, OD

Fink, Moshe, OG

Gadsden, S. Andrew, 03

Gamble, Joseph D., 08

Gann, Derek, 08

Gross, Barry, OG

Gross, Kevin C., OK

Harguess, Josh, OE, OF

Hawks, Michael, OK

Henry, Daniel J., 02

Hirsch, Michael, 06

Hu, Jun, OD

Irvine, John, $\mathrm{OE}$

Johnson, D., OC

Kalukin, Andrew, OE

Karasikov, Nir, 09

Kim, Jinho, 03

Korpela, Christopher, 03

Kover, Thomas, OD

Leake, Skye, 06

Lightstone, Samuel, OG

Luey, Benjamin, 08

Maltenfort, A. J., OE

McCormick, K., OC

McGuire, Thomas, 06

Moser, Eric K., OB

Moshary, Fred, OG

Müller, Thomas, 0J

Nolan, P., OC

Parsons, Michael, 06

Peled, Gal, 09

Rommel, Scott D., 08

Root, Philip, 03

Southall, Ben, OD

Spence, Clay D., OD

Starodubov, D., OC

Steward, Bryan J., OK

Straub, Jeremy, 06

Tozzo, Alex, OD

Volfson, L., OC

Wilkerson, Stephen, 03
Willner, A., OC

Yasinov, Roman, 09

Yetkariov, Rita, 09

Young, Shannon R., OK

Yuan, Xiaohui, 0 I

Ziemkiewicz, Michael, 08 
Proc. of SPIE Vol. $9828982801-6$

Downloaded From: https://www.spiedigitallibrary.org/conference-proceedings-of-spie on 26 Apr 2023 Terms of Use: https://www.spiedigitallibrary.org/terms-of-use 


\title{
Conference Committee
}

\author{
Symposium Chair
}

David A. Logan, BAE Systems (United States)

Symposium Co-chair

Donald A. Reago Jr., U.S. Army Night Vision \& Electronic Sensors Directorate (United States)

Conference Chair

Daniel J. Henry, Rockwell Collins, Inc. (United States)

Conference Co-chairs

Gregory J. Gosian, L-3 Communications (United States)

Davis A. Lange, UTC Aerospace Systems (United States)

Dale Linne von Berg, U.S. Naval Research Laboratory (United States)

Thomas J. Walls, U.S. Naval Research Laboratory (United States)

Darrell L. Young, Raytheon Intelligence \& Information Systems

(United States)

Session Chairs

1 ISR: Platforms and Missions

Dale Linne von Berg, U.S. Naval Research Laboratory (United States)

2 ISR: Optics and Stabilization

Davis A. Lange, UTC Aerospace Systems (United States)

3 ISR: Sensors and Systems

Thomas J. Walls, U.S. Naval Research Laboratory (United States)

4 ISR: Information Extraction/Quantification

Darrell L. Young, Raytheon Intelligence \& Information Systems

(United States)

5 ISR: Image Processing

Gregory J. Gosian, L-3 Communications (United States) 
Proc. of SPIE Vol. $9828982801-8$

Downloaded From: https://www.spiedigitallibrary.org/conference-proceedings-of-spie on 26 Apr 2023 Terms of Use: https://www.spiedigitallibrary.org/terms-of-use 


\section{Introduction}

This year's conference brought a wide range of papers related to Airborne ISR Systems and Applications. The conference was broken into multiple sessions, which addressed several different parts of the ISR TCPED image chain (Tasking, Capture, Processing, Exploitation, and Dissemination):

1. Platforms and Missions

2. Optics and Stabilization

3. Sensors and Systems

4. Information Extraction/Quantification

5. Image Processing

I would like to thank all of the authors for their efforts in making our conference such a success. We greatly appreciate them for writing and presenting their papers, as well as for their innovations in this exciting field that make our conference better each year. I look forward to the 2017 conference to see what additional advances have been made in these areas and what new technologies have been developed.

See you at Defense + Commercial Sensing 2017!

Sincerely,

Daniel J. Henry 
Proc. of SPIE Vol. $9828982801-10$

Downloaded From: https://www.spiedigitallibrary.org/conference-proceedings-of-spie on 26 Apr 2023 Terms of Use: https://www.spiedigitallibrary.org/terms-of-use 